\title{
Article
}

\section{Grazing Management Targets for Tangolagrass Pastures}

\author{
Nemora Guliane Mocelin ${ }^{1}$, Daniel Schmitt ${ }^{1}$ *(D), Guilherme Doneda Zanini ${ }^{2}$, Pedro Antonio Garzón Camacho ${ }^{1}$ \\ and André Fischer Sbrissia ${ }^{1}$ (D)
}

1 Animal Production and Food Science Department, Santa Catarina State University, Avenida Luiz de Camões, 2090, Lages 88520-000, Brazil; nemoragulianemocelin@gmail.com (N.G.M.); pedroagarzonc@gmail.com (P.A.G.C.); andre.sbrissia@udesc.br (A.F.S.)

2 Agronomy Department, “Barriga Verde" University, Rua Pe João Leonir Dall'Alba, 601, Orleans 88870-000, Brazil; guilhermedonedazanini@gmail.com

* Correspondence: daniel.schmitt@veterinario.med.br

check for updates

Citation: Mocelin, N.G.; Schmitt, D.; Zanini, G.D.; Camacho, P.A.G.;

Sbrissia, A.F. Grazing Management Targets for Tangolagrass Pastures. Agriculture 2022, 12, 279. https:/ / doi.org/10.3390/agriculture12020279

Academic Editors: Simone Ravetto Enri and Marco Pittarello

Received: 11 January 2022

Accepted: 10 February 2022

Published: 16 February 2022

Publisher's Note: MDPI stays neutral with regard to jurisdictional claims in published maps and institutional affiliations.

Copyright: () 2022 by the authors Licensee MDPI, Basel, Switzerland. This article is an open access article distributed under the terms and conditions of the Creative Commons Attribution (CC BY) license (https:// creativecommons.org/licenses/by/ $4.0 /)$.

\begin{abstract}
Tangolagrass (Brachiaria arrecta $\times$ Brachiaria mutica) is a stoloniferous warm-season grass considered as an alternative to forming permanent grasslands in waterlogged tropical regions. However, information about grazing management targets for such species is still scarce. This twoyear study aimed to identify pre-grazing canopy heights that do not compromise both leaf lamina production and nutritive value of tangolagrass pastures, and to test whether lower canopy height could decrease stolon elongation process. To this end, three pre-grazing canopy heights (20, 30, or $40 \mathrm{~cm}$, all lowered in $40 \%$ of their initial heights) were assigned to nine $390-\mathrm{m}^{2}$ plots grazed by cattle. Herbage, leaf, and stem accumulation rates were not different among treatments $(57,23$, and $27 \mathrm{~kg} \mathrm{DM} \mathrm{ha}^{-1} \mathrm{~d}^{-1}$, respectively; $p>0.05$ ). Also, neutral detergent fiber (NDF) and acid detergent fiber (ADF) were similar among treatments (56 and 24\% DM, respectively; $p>0.05$ ), but crude protein $(\mathrm{CP})$ was greater $(p=0.0180)$ in pastures managed with $30 \mathrm{~cm}(24.7 \% \mathrm{DM} \times 22.5 \% \mathrm{DM})$. Thus, pre-grazing canopy heights between $20-40 \mathrm{~cm}$ combined with low levels of defoliation (up to $40 \%$ of the initial height) provide the same primary productivity in tangolagrass pastures. However, stolon elongation could not be reduced within such canopy height targets.
\end{abstract}

Keywords: Brachiaria; canopy height; nutritive value; productivity; tangola

\section{Introduction}

Tangolagrass is a perennial warm-season grass originated from a natural hybridization between tannergrass (Brachiaria arrecta [Dur \& Schinz] Stent) and angolagrass (Brachiaria mutica [Forssk.] Stapf.), that presents stoloniferous growth habit, spreads vigorously, forms a strong root system from nodes, and is well-adapted to poorly drained soils. Like other brachiariagrasses, it also has a greater herbage production capacity, tolerates marginal soil fertility conditions, and is resistant to trampling. Accordingly, tangolagrass is considered an alternative to forming permanent tropical grasslands in marginal areas, especially those intermittently affected by flooding or waterlogging [1,2]. Despite its advantages, data about both primary productivity and management targets for this species are still scarce.

Overall, grasslands can be managed within a range of canopy-based targets (herbage mass, leaf area index [LAI], or grazing height) without compromising net herbage production [3-7]. This amplitude is due to "homeostatic" mechanisms that operate at the community level, whereby compensatory changes in tiller population density (TPD) and tissue flow buffer net herbage production [3,5,6]. Moreover, delaying grazing when the canopy reaches the critical LAI [8] in pastures under intermittent stocking, or by using taller grazing heights in pastures under continuous stocking, may increase leaf senescence and stem elongation rates [6,9-11]; thus, ultimately, decreasing net herbage production, nutritive value, and animal performance [12]. 
Despite the opportunities in terms of management targets, tangolagrass may present different accumulation patterns over grazing heights. This is because lower levels of defoliation or greater levels of light competition (both usually observed in taller canopies) can stimulate stolon elongation, whereas severe defoliations or greater light availability (both usually observed in lower canopies) can reduce stolon elongation $[13,14]$. Despite being important from an ecological perspective and contributing to herbage accumulation, stolon elongation can be undesirable for animal production since it involves the accumulation of stems, which reduces leaf:stem ratio and forage nutritive value [15,16], impairs bite formation $[17,18]$, and compromises animal performance $[19,20]$. Thus, it seems more appropriate to conceive grazing management strategies that reduce stolon elongation but at the same time do not compromise leaf lamina production when using tangolagrass pastures.

Against this background, we performed a study to identify pre-grazing canopy heights that do not compromise both leaf lamina production and the nutritive value of tangolagrass pastures subjected to intermittent stocking. Also, we tested the hypothesis that grazing management strategies can modulate stolon elongation/stem accumulation in tangolagrass swards.

\section{Materials and Methods}

The experiment was conducted in Orleans, SC, Brazil $\left(29^{\circ} 35^{\prime} \mathrm{S}\right.$ and $\left.49^{\circ} 25^{\prime} \mathrm{W}\right)$, during two experimental years (from January to June 2018 and 2019) on a well-established tangolagrass pasture. According to the Köppen climate classification, the region has a Cfa-type climate (humid subtropical under oceanic influences) with a hot summer and no dry season [21]. The average temperature and monthly precipitation during the experimental period are presented in Table 1 . The soil at the site is a clay loam red-yellow Ultisols [22], and its chemical characteristics at the 0 - to $20-\mathrm{cm}$ profile were assessed before starting the experiment (Table 2). Based on the Fertilizing and Liming Manual for the States of Rio Grande do Sul and Santa Catarina [23], 1.6 ton ha ${ }^{-1}$ of dolomitic limestone (on 29 December 2017), $50 \mathrm{~kg} \mathrm{~N} \mathrm{ha}^{-1}$ (on 16 January 2018; 28 February 2018; 22 January 2019; and 20 March 2019), $190 \mathrm{~kg} \mathrm{P} \mathrm{ha}^{-1}$ and $115 \mathrm{~kg} \mathrm{~K} \mathrm{ha}^{-1}$ (both on 15 December 2018) were applied. Before starting the experiment (on 11 December 2017), the whole area was mowed to a 5-cm stubble height.

Table 1. Monthly weather data during the experiment in Orleans, SC, Brazil.

\begin{tabular}{ccccc}
\hline \multirow{2}{*}{ Month } & \multicolumn{2}{c}{ Average Temperature $\left({ }^{\circ} \mathbf{C}\right)$} & \multicolumn{2}{c}{ Monthly Precipitation $(\mathbf{m m})$} \\
\cline { 2 - 5 } & $\mathbf{2 0 1 8}$ & $\mathbf{2 0 1 9}$ & $\mathbf{2 0 1 8}$ & $\mathbf{2 0 1 9}$ \\
\hline January & 24.6 & 27.1 & 120.6 & 112.9 \\
February & 24.5 & 24.8 & 30.5 & 105.9 \\
March & 24.7 & 22.8 & 99.9 & 76.9 \\
April & 24.1 & 22.4 & 23.1 & 426.1 \\
May & 20.6 & 12.7 & 111.4 & 357.8 \\
June & 17.1 & 12.6 & 125.4 & 23.7 \\
\hline
\end{tabular}

Table 2. Soil chemical characteristics (0-20 cm depth) of the experimental area before starting the experiment.

\begin{tabular}{|c|c|c|c|c|c|c|}
\hline \multirow{2}{*}{ Block } & \multirow{2}{*}{$\mathrm{pH}$} & $\mathrm{OM}^{1}$ & $\mathbf{P}$ & $\mathbf{K}$ & $\mathrm{H}+\mathrm{Al}$ & CEC \\
\hline & & $\%$ & \multicolumn{2}{|c|}{$\mathrm{mg} \mathrm{dm}^{-3}$} & \multicolumn{2}{|c|}{ cmolc dm ${ }^{-3}$} \\
\hline I & 6.4 & 1.4 & 2.0 & 88 & 6.5 & 5.54 \\
\hline II & 6.4 & 1.5 & 1.9 & 55 & 8.1 & 5.62 \\
\hline III & 6.2 & 2.0 & 2.5 & 74 & 11.4 & 6.37 \\
\hline
\end{tabular}

${ }^{1} \mathrm{pH}$ in $\mathrm{H}_{2} \mathrm{O}$; OM, organic matter; $\mathrm{P}$, phosphorous (Melich-1); $\mathrm{K}$, potassium (Melich-1); $\mathrm{H}+\mathrm{Al}$, potential acidity CEC, cation exchange capacity. 
The treatments corresponded to three pre-grazing canopy heights $(20,30$, and $40 \mathrm{~cm})$ grazed in $40 \%$ of their initial heights (stubbles of 12, 18, and $24 \mathrm{~cm}$, respectively). We chose the pre-grazing targets based on: (i) Andrade et al. [1], which recommended canopy heights around 40-45 cm for tangolagrass under intermittent stocking; and (ii) to test whether stolon elongation/stem accumulation could be reduced at lower heights. The intensity of defoliation was intended to not compromise herbage production [24] and intake by cattle [25]. We allocated the treatments across nine $390-\mathrm{m}^{2}$ plots following a complete randomized block design. Canopy heights were monitored using a ruler at 40 random points per plot twice a week during the regrowth period and every day during grazing. The animals used in this experiment were Angus steers and heifers (Bos taurus taurus), and the stocking densities were adjusted to achieve the intended post-grazing height target into $24 \mathrm{~h}$. The rest periods corresponded to the time necessary for the canopies to reach the intended plot's pre-grazing height.

Pre- and post-grazing herbage samples were collected in four random points per plot using $0.5-\mathrm{m}^{2}(1.0 \mathrm{~m} \times 0.5 \mathrm{~m})$ metallic frames, and cuttings were performed at the ground level. After being collected, all samples were fresh-weighted and processed as follows: (i) approximately $\frac{1}{4}$ of each sample was manually separated into plant parts (leaves, stems + pseudostems [named hereafter as stems], and dead material), stored in paper bags and dried in a forced-draft oven at $65^{\circ} \mathrm{C}$ to constant weight; (ii) the remaining materials (approximately $\frac{3}{4}$ of each sample) were stored in paper bags and also dried in a forced-draft oven at $65{ }^{\circ} \mathrm{C}$ to constant weight. It is worth mentioning that: (i) we chose not to separate stems from pseudostems (i.e., leaf sheath) because this is difficult to perform with the naked eye and both structures promote the same effect on the ingestive behavior of grazing animals [17]; (ii) this approach describes the whole canopy structure (and not the grazing layer offered to the animals). After drying, all materials were weighted separately and used to calculate plant-part composition (leaves, stems, dead material; \%) and herbage mass (plant-part components + remaining material; $\mathrm{kg} \mathrm{DM} \mathrm{ha}^{-1}$ ). Herbage accumulation was calculated as: HAc ${ }_{\text {Cycle } \mathrm{n}}=$ pre-grazing herbage mass Cycle $\mathrm{n}_{-}$- post-grazing herbage mass Cycle $\mathrm{n}-1 ;\left(\mathrm{kg} \mathrm{DM} \mathrm{ha}^{-1}\right)$; herbage accumulation rate $=\mathrm{HAcR}_{\text {Cycle } \mathrm{n}}=\mathrm{HAc}$ Cycle $\mathrm{n} /$ interval on days between Cycle $\mathrm{n}$ and Cycle $\mathrm{n}-1 ; \mathrm{kg} \mathrm{DM} \mathrm{ha}^{-1} \mathrm{~d}^{-1}$ ); leaf accumulation rate $=$ LAcR Cycle $\mathrm{n}=$ HAcR Cycle $\mathrm{n} \times \%$ leaves; $\mathrm{kg} \mathrm{DM} \mathrm{ha}^{-1} \mathrm{~d}^{-1}$ and stem accumulation rates $=$ SAcR Cycle $\mathrm{n}=$ HAcR Cycle $\mathrm{n} \times \%$ stems; $\mathrm{kg} \mathrm{DM} \mathrm{ha}^{-1} \mathrm{~d}^{-1}$ ). It should be mentioned that herbage accumulation and herbage accumulation rates corresponding to the first grazing cycle were calculated considering the date of the spring mowing (on 11 December 2017) and the whole herbage accumulated above the $5-\mathrm{cm}$ stubble.

Tiller population density (TPD) was estimated at pre-grazing by counting separately all aerial and basal tillers contained in four points per plot using a $0.5-\mathrm{m}^{2}(1.0 \mathrm{~m} \times 0.5 \mathrm{~m})$ metallic frame. The average leaf area per tiller (LA) was assessed as follows: (i) at the beginning of the experimental period, 100 tillers per plot had their leaf lamina detached, measured according to their length (from the ligule to the tip of the leaf lamina; LL) and width (at the middle point of their length; LW), and individually scanned in a leaf area meter (LI-COR, Model LI-3100A); (ii) then, the calculated leaf area (LAc; product between LL and LW) was regressed against the scanned leaf area (LA; Figure 1), and the formula was used to calculate LAs throughout the experiment; (iii) thus, 50 leaf lamina per plot were collected at pre- and post-grazing to calculate LA. Finally, the leaf area index (LAI) was calculated by the product between TPD and LA.

Herbage chemical composition was assessed from hand-plucked samples (Wallis de Vries, 1995). For this purpose, approximately $500 \mathrm{~g}$ of fresh herbage were collected every pre-grazing to simulate animal harvesting (based on visual assessments) and dried in a forced-draft oven at $65{ }^{\circ} \mathrm{C}$ to constant weight. Later, they were ground in a Willey mill to pass through a 1-mm screen and stored. The neutral detergent fiber (NDF) and acid detergent fiber (ADF) concentrations were determined according to the A200 Filter Bag Technique, Method 6 and 5, respectively [26,27]. Nitrogen concentration was measured using a micro-Kjeldahl technique, and the $\mathrm{CP}$ concentration calculated as $\mathrm{N} \times 6.25$. 


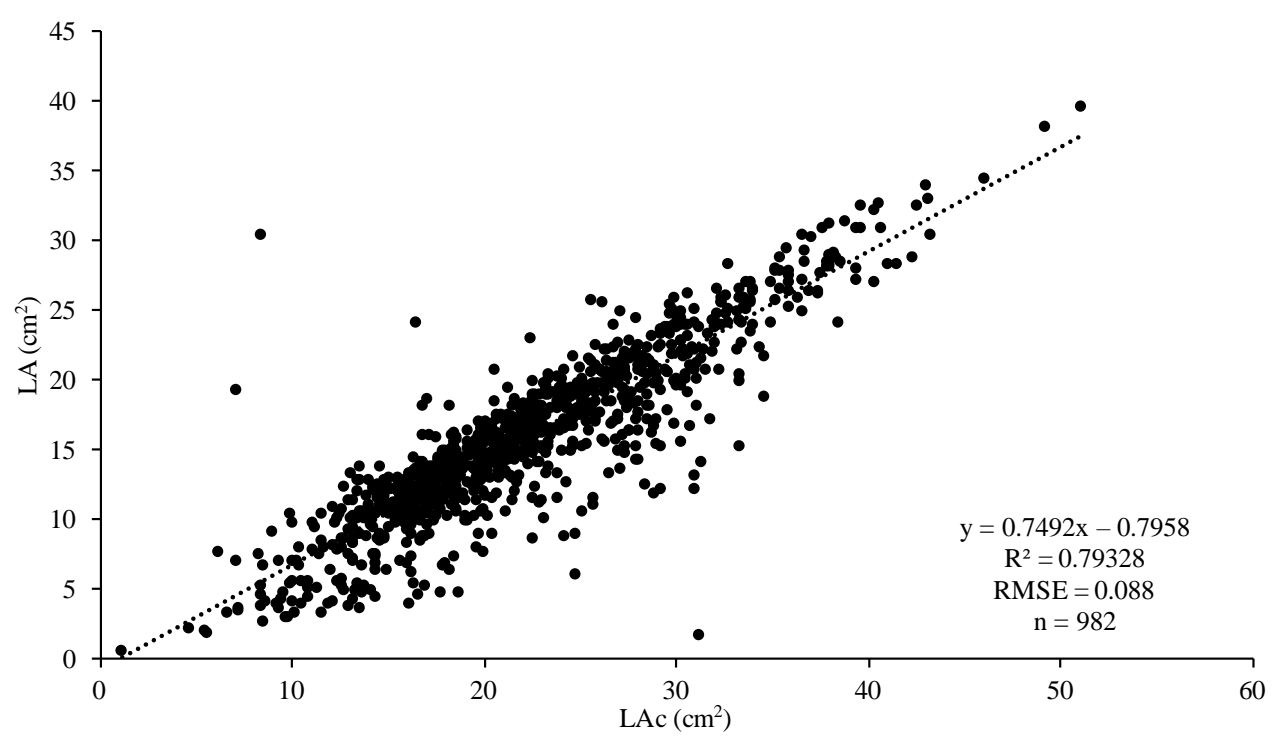

Figure 1. Regression between calculated leaf area (by assessing leaf length $\times$ leaf width; LAc) and scanned leaf area (by using the leaf area meter LI-COR, Model LI-3000A; LA) of tangolagrass.

Statistical analyses were performed using the MIXED procedure of the SAS statistical package with a model including the fixed effect of grazing height. The years were considered as a random effect. Grazing cycles within years were considered as repeated measurements [28]. The choice for the covariance matrix was made using the Akaike information criterion, and the mean values were compared using PDIFF by the Tukey-Kramer test. The significance for all analyses was set at $5 \%(p<0.05)$.

\section{Results}

There were no differences in herbage ( $p=0.7452)$, leaf $(p=0.7943)$, and stem $(p=0.6630)$ accumulation rate among treatments, with averages of 57,23 , and $27 \mathrm{~kg} \mathrm{DM} \mathrm{ha}{ }^{-1} \mathrm{~d}^{-1}$ (Figure 2), respectively. Also, tiller population density $(p=0.2436)$ and pre- and postgrazing leaf area index ( $p=0.1646$ and $p=0.4528$, respectively) did not vary among treatments (Table 3).

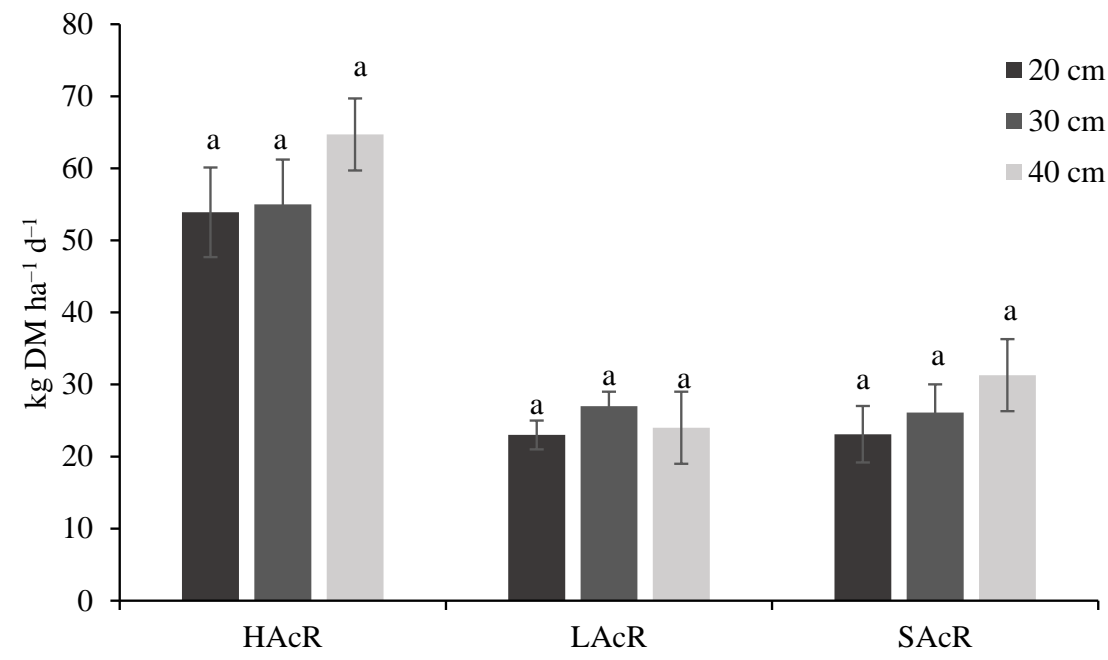

Figure 2. Average herbage (HAcR), leaf (LAcR), and stem accumulation rate (SAcR; $\mathrm{kg} \mathrm{DM} \mathrm{ha}^{-1} \mathrm{~d}^{-1}$ ) of tangolagrass pastures subjected to different pre-grazing height targets $(20,30$, or $40 \mathrm{~cm})$ and the same intensity of defoliation ( $40 \%$ of the initial height). Vertical error bars correspond to the standard error of the mean (SEM). For each variable, means followed by the same letter do not differ by the Tukey-Kramer test $(p<0.05)$. 
Table 3. Average tiller population density (tillers $\mathrm{m}^{-2}$; TPD), and pre- and post-grazing leaf area index (LAI pre and LAI post, respectively) of tangolagrass pastures subjected to different pre-grazing height targets $(20,30$, or $40 \mathrm{~cm})$ and the same intensity of defoliation ( $40 \%$ of the initial height).

\begin{tabular}{ccccc}
\hline \multirow{2}{*}{ Variable } & \multicolumn{3}{c}{ Height $(\mathbf{c m})$} & SEM \\
\cline { 2 - 4 } & $\mathbf{2 0}$ & $\mathbf{3 0}$ & $\mathbf{4 0}$ & \\
\hline TPD $^{1}$ & $1190^{\mathrm{A}}$ & $1290^{\mathrm{A}}$ & $1130^{\mathrm{A}}$ & 97.4 \\
LAI pre & $1.9^{\mathrm{A}}$ & $2.1^{\mathrm{A}}$ & $2.5^{\mathrm{A}}$ & 0.22 \\
LAI post & $0.8^{\mathrm{A}}$ & $0.5^{\mathrm{A}}$ & $0.6^{\mathrm{A}}$ & 0.33 \\
\hline
\end{tabular}

${ }^{1}$ Means followed by the same letter in rows do not differ by the Tukey-Kramer test $(p<0.05)$. SEM, standard error of the mean.

Pre-grazing herbage mass was affected by treatments $(p=0.0328$; Table 4$)$. In this way, plots managed with $40 \mathrm{~cm}$ presented greater herbage mass $\left(4470 \mathrm{~kg} \mathrm{DM} \mathrm{ha}^{-1}\right)$ than those managed with 20 or $30 \mathrm{~cm}$ (averaging $3560 \mathrm{~kg} \mathrm{DM} \mathrm{ha}^{-1}$ ). Plant-part composition at pre-grazing, however, was the same among treatments, and the mean values for leaves $(p=0.1866)$, stems $(p=0.7668)$, and senescent tissues $(p=0.8495)$ proportions were 23,47 , and 27, respectively (Table 4). Post-grazing herbage mass also differed among treatments $(p=0.0189$; Table 4$)$. In this way, plots managed with 30 and $40 \mathrm{~cm}$ presented greater herbage mass (averaging $2295 \mathrm{~kg} \mathrm{DM} \mathrm{ha}^{-1}$ ) than those managed with 20 (averaging $1820 \mathrm{~kg} \mathrm{DM} \mathrm{ha}^{-1}$ ).

Table 4. Pre- and post-grazing herbage mass ( $\left.\mathrm{kg} \mathrm{DM} \mathrm{ha}^{-1} ; \mathrm{HM}\right)$ and plant-part composition (leaves, stems, and senescent tissues; \%) of tangolagrass pastures subjected to different pre-grazing height targets $(20,30$, or $40 \mathrm{~cm})$ and the same intensity of defoliation ( $40 \%$ of the initial height).

\begin{tabular}{ccccc}
\hline \multirow{2}{*}{ Variable } & \multicolumn{3}{c}{ Height $\mathbf{( c m )}$} & SEM \\
\cline { 2 - 4 } & $\mathbf{2 0}$ & $\mathbf{3 0}$ & $\mathbf{4 0}$ \\
\hline & \multicolumn{3}{c}{ Pre-grazing } \\
\hline HM & $3430^{\mathrm{B}}$ & $3710^{\mathrm{B}}$ & $4470^{\mathrm{A}}$ & 201 \\
Leaves & $25^{\mathrm{A}}$ & $22^{\mathrm{A}}$ & $22^{\mathrm{A}}$ & 1.31 \\
Stems & $45^{\mathrm{A}}$ & $47^{\mathrm{A}}$ & $49^{\mathrm{A}}$ & 1.98 \\
Senesc. tissues & $26^{\mathrm{A}}$ & $28^{\mathrm{A}}$ & $27^{\mathrm{A}}$ & 2.49 \\
\hline & & Post-grazing & & 165 \\
HM & $1820^{\mathrm{B}}$ & $230^{\mathrm{A}}$ & $2280^{\mathrm{A}}$ & 1.74 \\
Leaves & $9^{\mathrm{A}}$ & $8^{\mathrm{A}}$ & $8^{\mathrm{A}}$ & 1.82 \\
Stems & $48^{\mathrm{A}}$ & $48^{\mathrm{A}}$ & $50^{\mathrm{A}}$ & 1.85 \\
\hline Senesc. tissues & $38^{\mathrm{A}}$ & $40^{\mathrm{A}}$ & $39^{\mathrm{A}}$ & \\
\hline
\end{tabular}

${ }^{1}$ Means followed by the same letter in rows do not differ by the Tukey-Kramer test $(p<0.05)$.

Plant-part composition at post-grazing was the same among treatments, and the mean values for leaves $(p=0.3022)$, stems $(p=0.7668)$, and senescent tissues $(p=0.7639)$ proportions were 8.3, 48.7, and 39.0, respectively (Table 4 ). There were no differences for neutral $(p=0.1793)$ and acid detergent fiber $(p=0.2298)$, with averages of 56.7 and $25.0 \%$ DM (Table 5), respectively. Crude protein, however, varied among treatments $(p=0.0180)$. In this way, plots managed with $30 \mathrm{~cm}$ presented crude protein contents higher than those managed with 20 or $40 \mathrm{~cm}$ (Table 5). 
Table 5. Chemical composition (neutral detergent fiber, NDF; acid detergent fiber, ADF; and crude protein, $\mathrm{CP}$; on \% DM basis) of hand-plucked herbage samples of tangolagrass pastures subjected to different pre-grazing height targets $(20,30$, or $40 \mathrm{~cm})$ and the same intensity of defoliation ( $40 \%$ of the initial height).

\begin{tabular}{ccccc}
\hline \multirow{2}{*}{ Variable } & \multicolumn{3}{c}{ Height $(\mathbf{c m})$} & \multirow{2}{*}{ SEM } \\
\cline { 2 - 4 } & $\mathbf{2 0}$ & $\mathbf{3 0}$ & $\mathbf{4 0}$ & \\
\hline $\mathrm{NDF}^{1}$ & $55.0^{\mathrm{A}}$ & $57.2^{\mathrm{A}}$ & $57.9^{\mathrm{A}}$ & 1.97 \\
$\mathrm{ADF}$ & $23.7^{\mathrm{A}}$ & $25.2^{\mathrm{A}}$ & $26.0^{\mathrm{A}}$ & 0.95 \\
$\mathrm{CP}$ & $22.4^{\mathrm{A}}$ & $24.7^{\mathrm{A}}$ & $22.7^{\mathrm{B}}$ & 0.83 \\
\hline
\end{tabular}

${ }^{1}$ Means followed by the same letter in rows do not differ by the Tukey-Kramer test $(p<0.05)$.

\section{Discussion}

Herbage, leaf, and stem accumulation rates remained constant within a relatively wide range of pre-grazing canopy height targets (Figure 2). We attribute such a pattern of response to both: (i) an equivalence in leaf growth/senescence rates; and (ii) an important (great) stem accumulation process. According to Sbrissia et al. [5], higher leaf elongation rates (usually observed in taller canopies or with greater LAI) can be accompanied by higher senescence rates, which could balance each other and lead to similar levels of leaf accumulation rate. Thus, because in our experiment pre-grazing LAI increased only slightly as grazing height increased (Table 3), the balance between leaf growth and senescence may have been similar among treatments. Regarding stem accumulation rate, it was not reduced by grazing height as expected; instead, it was rather high and constant among treatments. Thus, stem/stolon elongation in tangolagrass pastures seems to have a strong genetic programming that is only slightly modulated by managements based on canopy heights. Data with elephantgrass had already shown such genetic programming [29], but it is normally thought that grazing management can delay such processes $[30,31]$. Finally, because pastures presented similar leaf and stem accumulation rates, the total herbage production rate was also similar among treatments (Figure 2).

Generally, canopies present an inverse relationship between TPD and tiller size, a well-studied ecological process that has already been frequently reported in the scientific literature [32-35]. Ultimately, such a mechanism is comprehended as a response of plant communities to adjust LAI over a range of canopy targets (e.g., height, mass, or LAI). However, this classical mechanism was not observed in our study since, despite the apparent differences in tiller size (data not shown, but it can be easily assessed dividing herbage mass [Table 4] by TPD [Table 3]), the TPD remained constant among treatments (Table 3). In this context, we hypothesize that the similar LAI (note that it just increased slightly in our study; Table 3) across a range of canopy heights could be related to a specific and strong genetic programming (exactly like stem/stolon mentioned above) for leaf number and size. Nevertheless, because total herbage and leaf production were not affected over a range of pre-grazing canopy heights ( $20-40 \mathrm{~cm}$; Figure 2$)$, tangolagrass presents great flexibility in terms of canopy height targets, as already reported for other warm-season grasses such as kikuyugrass (Pennisetum clandestinum Hochst. Ex Chiov) [5] and marandu palisadegrass (Brachiaria brizantha [A. Rich.] Stapf.) [6].

Plant-part composition at pre- and post-grazing was constant among treatments; moreover, pastures presented a significant proportion of stems (averaging $47 \%$; Table 4). Such a pattern of response, once again, demonstrates that stems compose a significant amount of the vegetative growth in tangolagrass swards. Thus, it reinforces the observed lower pre- and post-grazing LAI (Table 3). Therefore, the use of tangolagrass in intensive grazing management systems would require greater herbage allowances and lower intensities of defoliation. It would be necessary to allow animals the possibility of selecting leaves (improving diet quality; [36,37], and also leaving leafier stubbles (increasing regrowth potential; [4,24]). 
In general, the chemical composition of hand-plucked herbage samples was little affected by the canopy heights considered in our study (Table 5). Schmitt et al. [25] reported that herbage morphological and chemical composition in the canopy upper half does not change within a range of pre-grazing heights, provided moderate levels of defoliations (up to 50\%) are used. Finally, the unexpected higher CP content can be a consequence of: (i) an excessive accumulation of non-protein $\mathrm{N}$, which could have overestimate $\mathrm{CP}$ or (ii) since tangolagrass presents short leaves it would require less thick-walled structures (e.g., midrib; [2].

Finally, it worth mentioning that the experiment was thought to have a fourth treatment (canopy height of $10 \mathrm{~cm}$ ). However, after a few months, pastures subjected to a grazing height of $10 \mathrm{~cm}$ lost vigor and became completely infested by weeds (only $\pm 20 \%$ of the herbage mass was composed of tangolagrass in this treatment). Such a pattern of response demonstrates that, despite the wide range of pre-grazing canopy targets that can be used for this plant $(20-40 \mathrm{~cm})$, it should not be managed at grazing heights lower than $20 \mathrm{~cm}$, or by using severe intensities of defoliation.

\section{Conclusions}

Tangolagrass pastures managed under pre-grazing canopy heights between $20-40 \mathrm{~cm}$ combined with low levels of defoliation (at least up to $40 \%$ of the initial height) present the same primary productivity. However, stem/stolon elongation in tangolagrass is a processe that cannot be reduced by management techniques based on canopy height targets.

Author Contributions: Conceptualization: N.G.M., G.D.Z. and A.F.S.; methodology: N.G.M., G.D.Z. and A.F.S.; formal analysis: N.G.M., D.S. and A.F.S.; investigation: N.G.M. and G.D.Z.; resources: G.D.Z. and A.F.S.; data curation, N.G.M. and A.F.S.; writing-original draft preparation, N.G.M., D.S. and A.F.S.; writing-review and editing, D.S., P.A.G.C. and A.F.S.; supervision, G.D.Z. and A.F.S. All authors have read and agreed to the published version of the manuscript.

Funding: This research was funded by FAPESC (2021 TR 543 and 2021 TR 813) and the APC was funded by CAPES 2020 DS 1478.

Data Availability Statement: The data presented in this study are openly available in ResearchGate at doi: $10.13140 /$ RG.2.2.35103.64167.

Conflicts of Interest: The authors declare no conflict of interest.

\section{References}

1. Andrade, C.M.S.; Assis, G.M.L.; Fazolin, M.; Gonçalves, R.C.; Sales, M.F.L.; Valentin, J.F.; Estrela, J.L.V. (Eds.) Capim-Tangola: Gramínea Forrageira Recomendada Para Solos de Baixa Permeabilidade do Acre; Embrapa Acre: Rio Branco, Brazil, 2009.

2. Queiroz, D.S.; Casagrande, D.R.; Moura, G.S.; Silva, E.A.; Viana, M.C.M.; Ruas, J.R.M. Espécies forrageiras para produção de leite em solos de várzea. R. Bras. Zootec. 2012, 41, 271-280. [CrossRef]

3. Bircham, J.S.; Hodgson, J. The influence of sward condition on rates of herbage growth and senescence in mixed swards under continuous stocking management. Grass Forage Sci. 1983, 38, 323-331. [CrossRef]

4. Parsons, A.J.; Johnson, I.R.; Harvey, A. Use of a model to optimize the interaction between frequency and severity of intermittent defoliation and to provide a fundamental comparison of the continuous and intermittent defoliation of grass. Grass Forage Sci. 1988, 43, 49-59. [CrossRef]

5. Sbrissia, A.F.; Duchini, P.G.; Zanini, G.D.; Santos, G.T.; Padilha, D.A.; Schmitt, D. Defoliation strategies in pastures submitted to intermittent stocking method: Underlying mechanisms buffering forage accumulation over a range of grazing heights. Crop Sci. 2018, 58, 945-954. [CrossRef]

6. Sbrissia, A.F.; Schmitt, D.; Duchini, P.G.; Da Silva, S.C. Unravelling the relationship between a seasonal environment and the dynamics of forage growth in grazed swards. J. Agron. Crop Sci. 2020, 206, 630-639. [CrossRef]

7. Zanella, P.G.; Junior, L.H.P.D.G.; Pinto, C.E.; Baldissera, T.C.; Werner, S.S.; Garagorry, F.C.; Jaurena, M.; Lattanzi, F.A.; Sbrissia, A.F. Grazing intensity drives plant diversity but does not affect forage production in a natural grassland dominated by the tussock-forming grass Andropogon lateralis Nees. Sci. Rep. 2021, 11, 16744. [CrossRef]

8. Brougham, R.W. Interception of light by the foliage of pure and mixed stands of pasture plants. Aust. J. Agric. Res. 1958, 9, 39-52. [CrossRef]

9. Carnevalli, R.A.; Da Silva, S.C.; Bueno, A.A.O.; Uebele, M.C.; Bueno, F.O.; Hodgson, J.; Silva, G.; Morais, J.P.G. Herbage production and grazing losses in Panicum maximum cv. Mombaça under four grazing managements. Trop. Grassl. 2006, 40, 165-176. 
10. Zanini, G.D.; Santos, G.T.; Sbrissia, A.F. Frequencies and intensities of defoliation in Aruana guineagrass swards: Morphogenetic and structural characteristics. R. Bras. Zootec. 2012, 41, 1848-1857. [CrossRef]

11. Migliorini, F.; Soares, A.B.; Schmitt, D.; Pontes, L.S.; Assmann, T. Morphogenetic and structural characteristics of Alexandergrass pastures under continuous stocking. Ciênc. Anim. Bras. 2018, 19, e50830. [CrossRef]

12. Da Silva, S.C.; Sbrissia, A.F.; Pereira, L.E.T. Ecophysiology of C4 forage grasses-Understanding plant growth for optimising their use and management. Agriculture 2015, 5, 598-625. [CrossRef]

13. Dong, M.; Pierdominici, M.G. Morphology and growth of stolons and rhizomes in three clonal grasses, as affected by different light supply. Vegetatio 1995, 116, 25-32. [CrossRef]

14. Wilen, C.A.; Holt, J.S. Spatial Growth of kikuyugrass (Pennisetum clandestinum). Weed Sci. 1996, 44, 323-330. [CrossRef]

15. Silva, V.J.; Pedreira, C.G.; Sollenberger, L.E.; Carvalho, M.S.; Tonato, F.; Basto, D.C. Seasonal herbage accumulation and nutritive value of irrigated 'Tifton 85', Jiggs, and Vaquero bermudagrasses in response to harvest frequency. Crop Sci. 2015, 55, 2886-2894. [CrossRef]

16. Wallau, M.O.; Sollenberger, L.E.; Vendramini, J.M.; Gomide, C.A.; Mullenix, M.K.; Quesenberry, K.H. Performance of limpograss breeding lines under various grazing management strategies. Crop Sci. 2016, 56, 3345-3353. [CrossRef]

17. Benvenutti, M.A.; Gordon, I.J.; Poppi, D.P. The effect of the density and physical properties of grass stems on the foraging behaviour and instantaneous intake rate by cattle grazing an artificial reproductive tropical sward. Grass Forage Sci. 2006, 61, 272-281. [CrossRef]

18. Mezzalira, J.C.; Carvalho, P.C.F.; Fonseca, L.; Bremm, C.; Cangiano, C.; Gonda, H.L.; Laca, E.A. Behavioural mechanisms of intake rate by heifers grazing swards of contrasting structures. Appl. Anim. Behav. Sci. 2014, 153, 1-9. [CrossRef]

19. Euclides, V.P.B.; Carpejani, G.C.; Montagner, D.B.; Nascimento Júnior, D.; Barbosa, R.A.; Difante, G.S. Maintaining post-grazing sward height of Panicum maximum (cv. Mombaça) at $50 \mathrm{~cm}$ led to higher animal performance compared with post-grazing height of $30 \mathrm{~cm}$. Grass Forage Sci. 2018, 73, 174-182. [CrossRef]

20. Congio, G.F.S.; Batalha, C.D.A.; Chiavegato, M.B.; Berndt, A.; Oliveira, P.P.A.; Frighetto, R.T.S.; Maxwell, T.M.R.; Gregorini, P.; Da Silva, S.C. Strategic grazing management towards sustainable intensification at tropical pasture-based dairy systems. Sci. Total Environ. 2018, 636, 872-880. [CrossRef]

21. Alvares, C.A.; Stape, J.L.; Sentelhas, P.C.; Gonçalves, J.L.M.; Sparovek, G. Köppen's climate classification map for Brazil. Meteorol. Z. 2013, 22, 711-728. [CrossRef]

22. Empresa Brasileira de Pesquisa Agropecuária (EMBRAPA). Sistema Brasileiro de Classificação de Solos; EMBRAPA Solos: Rio de Janeiro, Brazil, 2006.

23. Comissão de Química e Fertilidade do SoloRS/SC-CQFS. Manual de Adubação e Calagem para os Estados do Rio Grande do Sul e Santa Catarina; Sociedade Brasileira de Fertilidade do Solo: Porto Alegre, Brazil, 2004.

24. Martins, C.D.M.; Schmitt, D.; Duchini, P.G.; Miqueloto, T.; Sbrissia, A.F. Defoliation intensity and leaf area index recovery in defoliated swards: Implications for forage accumulation. Sci. Agric. 2021, 78, e20190095. [CrossRef]

25. Schmitt, D.; Padilha, D.A.; Dias, K.M.; Gabriela, T.S.; Rodolfo, G.R.; Zanini, G.D.; Sbrissia, A.F. Chemical composition of two warm-season perennial grasses subjected to proportions of defoliation. Grassl. Sci. 2019, 65, 171-178. [CrossRef]

26. Ankon Technology. Neutral Detergent Fiber in Feeds-Filter Bag Technique (for A200 and A200I). Method 6. ANKOM Technol. Macedon NY 2014. Available online: https:/ / www.ankom.com/sites/default/files/document-files/Method_6_NDF_A200.pdf (accessed on 5 January 2022).

27. Ankon Technology. Acid Detergent Fiber in Feeds-Filter Bag Technique (for A200 and A200I). Method 5. ANKOM Technol. Macedon NY 2014. Available online: https://www.ankom.com/sites/default/files/document-files/Method_5_ADF_A200.pdf (accessed on 5 January 2022).

28. Littell, R.C.; Stroup, W.W.; Milliken, G.A.; Wolfinger, R.D.; Schabenberger, O. (Eds.) SAS for Mixed Models; SAS Institute Inc.: Cary, NC, USA, 2006.

29. Portes Silva, G.; Da Silva, S.C.; Escobar-Guttiérrez, A.; Lemaire, G.; Louarn, G. Stem elongation in Pennisetum purpureum results from a fixed pattern of vegetative development potentially enhanced by the initiation of flowering. Grass Forage Sci. 2019, 74, 708-719. [CrossRef]

30. Pereira, L.E.T.; Paiva, A.J.; Geremia, E.V.; Silva, S.C. Regrowth patterns of elephant grass (Pennisetum purpureum Schum) subjected to strategies of intermittent stocking management. Grass Forage Sci. 2015, 70, 195-204. [CrossRef]

31. Rodolfo, G.R.; Schmitt, D.; Dias, K.M.; Sbrissia, A.F. Levels of defoliation and regrowth dynamics in elephant grass swards. Cienc. Rural 2015, 45, 1299-1304. [CrossRef]

32. Matthew, C.; Lemaire, G.; Sackville-Hamilton, N.R.; Hernández Garay, A. A modified self- thinning equation to describe size/density relationships for defoliated swards. Ann. Bot. 1995, 76, 579-587. [CrossRef]

33. Hernández Garay, A.; Matthew, C.; Hodgson, J. Tiller size/density compensation in perennial ryegrass miniature swards subject to differing defoliation heights and a proposed productivity index. Grass For. Sci. 1999, 54, 347-356. [CrossRef]

34. Sbrissia, A.F.; Da Silva, S.C. Compensação tamanho/densidade populacional de perfilhos em pastos de capim-marandu. R. Bras. Zootec. 2008, 37, 35-47. [CrossRef]

35. Martínez Calsina, L.; Agnusdei, M.G.; Assuero, S.G.; Pérez, H. Size/density compensation in Chloris gayana Kunth cv. Fine Cut subjected to different defoliation regimes. Grass For. Sci. 2012, 67, 255-262. [CrossRef] 
36. Da Trindade, J.K.; Da Silva, S.C.; Souza Júnior, S.J.; Giacomini, A.A.; Zeferino, C.V.; Guarda, V.D.A.; Carvalho, P.C.F. Composição morfológica da forragem consumida por bovinos de corte durante o rebaixamento do capim-marandu submetido a estratégias de pastejo rotativo. Pesqui. Agropecu. Bras. 2007, 42, 883-890. [CrossRef]

37. Rouquette, F.M. Invited Review: The roles of forage management, forage quality, and forage allowance in grazing research. Prof. Anim. Sci. 2016, 32, 10-18. [CrossRef] 